\title{
Selection of Dried and Table Apricots in Nevsehir and Nigde Regions, Turkey
}

\author{
Veyis YURTKULU ${ }^{1}$, Ali KÜDEN², Ayzin B. KÜDEN²* \\ ${ }^{1}$ The Ministry of Agriculture and Forestry, Ankara; veyisyurtkulu@gmail.com \\ ${ }^{2}$ University of Cukurova, Faculty of Agriculture, 01330 Balcali, Saricam, Adana, \\ Turkey;akuden@cu.edu.tr;abkuden@gmail.com (*correspondingauthor)
}

\begin{abstract}
Apricot, for which Turkey is recognized as a top producer and the leading country in the world, is one of the most produced stone fruits in Turkey. For long time ago, apricot has been grown with the nursery plants obtained from the seeds in Nevsehir and Nigde provinces caused a wide range of germplasm resources in this area (Cappadocia area). Each apricot tree shows different characteristics and could be a variety candidate. With this study, phenological and pomological characters of 91 genotypes were determined and among them 15 of the best promising genotypes were given in this paper. Considering the experimented 15 genotypes, 8 genotypes gave higher Brix value (SSC) (27-31\%) than 'Hacihaliloglu' variety (25-26\%) which was the most common dried apricot variety in Turkey. Regarding the fruit weight, which is an important aspect for both dried and table fruits, high valued genotypes were also determined. The fruit weight of 11 genotypes were higher than $50 \mathrm{~g}$ with the values between $51.45 \mathrm{~g}$ and $84.02 \mathrm{~g}$. As a result of this study, candidates for dried and table apricot genotypes were identified.
\end{abstract}

Keywords: breeding; drought conditions; elite germplasm; genetic codes; late blooming

\section{Introduction}

The climate and soil conditions of Turkey are very suitable to grow various fruit species in different parts of the country. It has also very rich with plant genetic materials and many fruit species are originated in Anatolia. Production and exportation of many fruit and vegetable species under suitable ecological conditions of Anatolia is one of the best proofs of this. Turkey is among the major fruit producing countries in the world in terms of number of fruit species and varieties and also the amount of the production. Apricot is one of them and Turkey takes the first rank in world production. Considering the purpose of apricot cultivation, dried apricot growing mainly takes place in Malatya, Elazig, Sivas (Gurun) and Kahramanmaras (Elbistan) provinces, while the production of table apricot takes place in the Mediterranean region including Mersin, Adana, Antalya and Isparta (Asma, 2007; 2012). According to many researchers, the homeland of apricots was China and Central Asia and transferred to Anatolia through Iran and the Caucasus during the Asia Campaign of Alexander the Great (BC330-323) (Özbek, 1978). 'Sekerpare', 'Aprikoz', 'Tokaloglu', 'Iri Bitirgen', 'Alyanak', 'Sakit' varieties are some of the domestic apricots, 'Roxana', 'Precoce de Tyrinthe', 'Ninfa', 'Priana', 'Beliana' and 'Feriana' are the introduced table apricot varieties grown in Turkey. 'Hacihaliloglu', 'Kabaası', 'Soganci' and 'Cataloglu' are the most important dried apricot varieties in the country.

The common traits and the prominent problems of dry and table apricot varieties in Malatya and its environmental area are as follows:

- Small fruit size (about 25-40 g).

- Large tree formation and plantation of $8 \times 8 \mathrm{~m}, 10 \mathrm{x} 10$ $\mathrm{m}$ intervals (not suitable for new high density orchard plantations). years.

- Juvenility period is very long and fruit set is about 5-6

- Sensitivity to late spring frosts.

For this reason, this experiment was carried out to identify new genotypes; suitable for drying, high sugar content (Brix value above 22-24), resistant/tolerant to late spring frosts, resistance/tolerant to low winter temperatures, having bigger fruit size more than $30 \mathrm{~g}$. In this study, morphological, phenological and pomological identification of the promising 15 genotypes for drying or table consumption were determined. 


\section{Materials and Methods}

Selected apricot genotypes used in this study were obtained from seeds over the years and wildly grown in Nevsehir and Nigde provinces and environments. Selected promising 15 apricot genotypes among 91 genotypes were the materials of this study.

In Nevsehir province, wildly grown apricot genotypes are 'Kavak', 'Kaymaklı', 'Göreme', 'Uçhisar', 'Sulusaray', 'Nar', 'Çat Towns', 'Derinkuyu', 'Özlüce Village', 'Ürgüp', 'Ortahisar', 'Ayvalı' and other surrounding villages, towns and locations were determined and sampled. Apricot genotypes in 'Niğde' province and in 'Ulukışla' district's villages and towns were also selected, marked and sampled.

\section{Marking the trees of the selected genotypes}

Firstly, the genotypes were selected and marked according to the yield of the tree, the quality of the fruits and the regular bearing habit.

The place and direction of the area where the selected genotypes found were recorded from the point view of the location, the latitude, longitude and altitude by GPS. Conditions such as approximate age of the tree, pruning, fertilizing and watering status, fruit cracking, the susceptibility of disease and pests were examined.

\section{Phenological observations}

Flowering periods of the genotypes were determined by observations. Bud break (the period in which $50 \%$ of the buds showed green tip), blooming initiation (the period when $5 \%$ of the flowers blossomed), full bloom (the period when $70 \%$ of the flowers blossomed) and petal fall period when $90 \%$ of the petal fall stage were observed.

\section{Pomological analyses}

Thirty fruits from each tree were collected during the fruit maturation period. All the pomological analysis (Fruit weight, height, width and thickness) were performed according to the International Plant Genetic Resources Apricot Identification Guide "IBPGR Revised Descriptor List for Apricot (Prunus armeniaca L.)”. Randomly taken 30 fruit samples from each genotype divided into three pieces each of which consisting of 10 fruits for each replication. The average values for fruit weight were classified as follows:

$\begin{array}{ll}\text { Small } & (<35 \mathrm{~g}) \\ \text { Small/Medium } & (35.01-45.00 \mathrm{~g}) \\ \text { Medium } & (45.01-60.00 \mathrm{~g}) \\ \text { Medium/Big } & (60.01-70.00 \mathrm{~g}) \\ \text { Big } & (>70 \mathrm{~g})\end{array}$

The fruit flesh firmness $\left(\mathrm{kg} / \mathrm{cm}^{2}\right)$, seed weight, fruit flesh/seed ratio, Brix value (\%), $\mathrm{pH}$, total acidity (\%) were also analyzed.

Data derived from observation and pomological analyses of the genotypes were evaluated with "Weighted Ranking Method".

In this evaluation, the most desired characteristics for table and dried apricot varieties such as high yield, good fruit size, high Brix value, low acidity, aroma, fruit flesh firmness, fruit flesh/seed ratio, the adherence of flesh to seed, were taken into consideration. The data of the traits were divided into classes according to Apricot Descriptor (Guerriero and Watkins, 1984) and for those classes 1-10 scoring was applied (10 was the best).

The sum of the weighted scores obtained as a result of multiplying the grade points and the relative scores of each feature gave the total value score of the varieties based on the "Weighted Ranking" and the highest total value scored ones were taken into consideration in the selection.

Budsticks were taken in the same year (2015) from the genotypes and grafted at the research and application orchards of University of Cukurova, Department of Horticulture.

\section{Results and Discussion}

In this apricot selection study, very promising genotypes for both table and dried apricots naturally and wildly grown in Nevşehir and Niğde provinces were found. These apricot genotypes were grown from the seeds without any irrigation, fertilization or any chemical applications for long time ago. Therefore, there is a large germplasm population in the area. The apricots that were cultivated in this way at the region called Bitirgen, which means that they were grown from the seeds. Morphological evaluations, pomological analyze and phenological observations were made between 2015 and 2017 period in apricot genotypes discussed in the study.

\section{Phenological observations}

Results of phenological observations and harvesting dates of apricot selected genotypes are given in Table 1. Generally, selected genotypes were bloomed 7 or 10 days later than 'Hacihaliloglu' and 'Kabaasi' varieties. Considering the harvesting time, the earliest ripening genotypes $50-\mathrm{K}-15$ and $50-\mathrm{K}-20$ were ripen $10-15$ days later than 'Hacihaliloglu' and 'Kabaasi' varieties (Table 1, Fig. 1).

\section{Pomological characteristics}

In pomological analysis of apricot genotypes, fruit thickness $(\mathrm{mm})$, fruit height $(\mathrm{mm})$, fruit width $(\mathrm{mm})$, fruit weight $(\mathrm{g})$, fruit flesh firmness $\left(\mathrm{kg} / \mathrm{cm}^{2}\right)$, Brix value $(\%) \mathrm{pH}$, total acidity (\%), seed weight (g) and fruit flesh/seed ratio were determined. For this aim apricot fruits for the pomological analyses were collected during tree maturation period and when the skin went yellow. All genotypes were evaluated with the Weighted Ranking Method. The average values of the characteristics obtained by Weighted Ranking Method after pomological analyses are given in Table 2 . Especially Brix value (\%) and fruit size were found to be important in pomological measurements. Brix value, which is a significant parameter especially for dried apricot production, (eight genotypes were identified having higher Brix value than 'Hacihaliloglu' (25-26\%), the most produced and exported dry apricot variety in Malatya province of Turkey. Brix values of the genotypes varied between 27-31\%. Genotype '50-K-91' (Fig. 2) gave the highest Brix value (31\%) and followed by ' $50-K-57$ ' (29\%), '50-K-93' (28\%), '50-K-94' (28\%), '51-K-06' (28\%), '50-K82 ' (27\%), '50-K-95' (27\%), '50-K-97' (27\%), '50-K-96' (26\%) genotypes and 'Hacihaliloğlu' variety (26\%). Brix values obtained by different researchers were: 9,53\% - 
430

21,03\% by Durgaç (2001), 16.6\% - 24.1\% by Asma (2012), $9.50 \%-20.12 \%$, by Şen et al. (1995), $14.6 \%-19.2 \%$, by Bolat and Güleryüz (1995). Extremely good results were obtained from the genotypes of ' $50-\mathrm{K}-96$ ' (26\%), '50-K-95', '50-K-97', '50-K-82', (27\%), '50-K-93', '51-K-06', '50-K-94' (28\%) and '50-K-57' (29\%) and '50-K-91' (31\%) with Brix value over $25 \%$ (Fig. 2 ).

Genotypes with higher fruit weight than 'Hacihaliloglu' were obtained for both dried and table apricot characteristics. Eleven genotypes gave over $50 \mathrm{~g}$ of fruit weight changed between $51.45 \mathrm{~g}$ and $84.02 \mathrm{~g}$. It could be a good opportunity to use them in future breeding studies since 'Hacihaliloglu' is smaller and having less Brix value than them. '50-K-17' (84.02 g) genotype took the first place for fruit weight and it was followed by ' $50-\mathrm{K}-20$ ' $(67.61 \mathrm{~g})$, '50-K-130' (65.26 g), '50-K-15’ (61.93 g), '50-K-81' (60.82 g) genotypes. The lowest fruit size was observed in ' $50-\mathrm{K}-95$ ' (30.31 g) and '50-K-96' (21.02 g) genotypes. These values were in accordance with the values of Özyörük and
Güleryüz (1992) in which average fruit weight was found between 24.9-62.1 g in Iğdır Plain for 'Şalak', 'Tebereze', 'Ağerik', 'Ordubat ve Ağcanabat' apricot varieties.

Akça and Şen (1999) evaluated growth habit, productivity, pomological and phenological characteristics of Gevas's selected apricots, resistant to late spring frost with high fruit quality. Average fruit weight of those types was found to be between 12.70 and $30.19 \mathrm{~g}$.

'Harcot' variety ranked the first place for fruit size with $69 \mathrm{~g}$ and the smallest fruits were obtained from 'Priana' with $25 \mathrm{~g}$, 'Beliana' with $30 \mathrm{~g}$ and 'Feriana' with $31 \mathrm{~g}$ by Pınar $e t$ al. (2010) in Mersin.

Akca and Askin (1995) found 17 types with fruit weight of 40.08 to $53.73 \mathrm{~g}$ in a clonal selection study carried out on 'Hacıhaliloğlu' apricot variety in Gurun. They found that the fruit size of the evaluated types formed between 15.73 and $84.02 \mathrm{~g}$. These values were similar with the varieties grown in Turkey and it was seen that first four types gave heavier fruit weight than the others.

Table 1. Results of phenological observation in apricot genotypes (2015-2017)

\begin{tabular}{|c|c|c|c|c|c|}
\hline Genotypes & $\begin{array}{l}\text { Ripening } \\
\text { dates }\end{array}$ & Bud Burst & First Bloom & $\begin{array}{c}\text { Full } \\
\text { Bloom }\end{array}$ & End of Bloom \\
\hline \multirow{2}{*}{ '50-K-15’ } & 23.07 .2015 & 18.03 .2015 & 28.03 .2015 & 06.04 .2015 & 17.04 .2015 \\
\hline & 13.07 .2017 & 12.03 .2017 & 22.03 .2017 & 01.04 .2017 & 11.04 .2017 \\
\hline \multirow{2}{*}{$` 50-\mathrm{K}-17$ ’ } & 23.07 .2015 & 18.03 .2015 & 29.03 .2015 & 04.04 .2015 & 14.04 .2015 \\
\hline & 22.07 .2017 & 13.03 .2017 & 23.03.2017 & 28.03 .2017 & 08.04 .2017 \\
\hline \multirow{2}{*}{ '50-K-20' } & 20.07 .2015 & 18.03 .2015 & 31.03 .2015 & 04.04 .2015 & 16.04 .2015 \\
\hline & 15.07 .2017 & 15.03 .2017 & 26.03 .2017 & 01.04 .2017 & 10.04 .2017 \\
\hline \multirow{2}{*}{ ‘50-K-57’ } & 21.07 .2015 & 22.03 .2015 & 29.03 .2015 & 05.04 .2015 & 16.04 .2015 \\
\hline & 19.07 .2017 & 18.03.2017 & 23.03 .2017 & 01.04 .2017 & 09.04 .2017 \\
\hline \multirow{2}{*}{ '50-K-91' } & 21.07 .2015 & 20.03 .2015 & 26.03 .2015 & 31.03 .2015 & 16.04 .2015 \\
\hline & 18.07 .2017 & 16.03 .2017 & 22.03 .2017 & 26.03 .2017 & 11.04 .2017 \\
\hline \multirow{2}{*}{ '50-K-92' } & 21.07 .2015 & 25.03 .2015 & 30.03 .2015 & 03.04 .2015 & 15.04 .2015 \\
\hline & 18.07.2017 & 21.03 .2017 & 25.03 .2017 & 01.04 .2017 & 10.04 .2017 \\
\hline \multirow{2}{*}{ '50-K-93' } & 21.07 .2015 & 17.03 .2015 & 27.03 .2015 & 31.03 .2015 & 16.04 .2015 \\
\hline & 17.07 .2017 & 12.03 .2017 & 23.03.2017 & 26.03 .2017 & 08.04 .2017 \\
\hline \multirow{2}{*}{ '50-K-95’ } & 01.08 .2015 & 20.03 .2015 & 30.03 .2015 & 05.04 .2015 & 15.04 .2015 \\
\hline & 25.07 .2017 & 15.03 .2017 & 24.03.2017 & 01.04 .2017 & 09.04 .2017 \\
\hline \multirow{2}{*}{$' 50-K-96 '$} & 01.08 .2015 & 22.03 .2015 & 02.04 .2015 & 08.04 .2015 & 15.04 .2015 \\
\hline & 24.07 .2017 & 17.03.2017 & 29.03 .2017 & 05.04 .2017 & 12.04 .2017 \\
\hline \multirow{2}{*}{ '50-K-97’ } & 21.07 .2015 & 23.03 .2015 & 03.04 .2015 & 09.04 .2015 & 16.04 .2015 \\
\hline & 19.07 .2017 & 20.03 .2017 & 01.04 .2017 & 07.04 .2017 & 12.04 .2017 \\
\hline \multirow{2}{*}{ ‘50-K-98’ } & 21.07 .2015 & 19.03 .2015 & 30.03 .2015 & 04.04 .2015 & 15.04 .2015 \\
\hline & 19.07 .2017 & 16.03 .2017 & 28.03 .2017 & 02.04 .2017 & 11.04 .2017 \\
\hline \multirow{2}{*}{$50-\mathrm{K}-130$} & 21.07 .2015 & 18.03 .2015 & 31.03 .2015 & 06.04 .2015 & 16.04 .2015 \\
\hline & 20.07 .2017 & 15.03 .2017 & 26.03 .2017 & 03.04 .2017 & 10.04 .2017 \\
\hline \multirow{2}{*}{ '51-K-06' } & 24.07 .2015 & 16.03 .2015 & 31.03 .2015 & 06.04 .2015 & 14.04 .2015 \\
\hline & 20.07 .2017 & 13.03.2017 & 27.03 .2017 & 01.04 .2017 & 09.04 .2017 \\
\hline \multirow{2}{*}{ 'Hacıhaliloğlu' } & 04.07 .2015 & 13.03.2015 & 24.03 .2015 & 27.03 .2015 & 08.04 .2015 \\
\hline & 02.07 .2017 & 10.03 .2017 & 22.03 .2017 & 25.03 .2017 & 06.04 .2017 \\
\hline \multirow{2}{*}{ 'Kabaaşı' } & 02.07 .2015 & 12.03 .2015 & 21.03 .2015 & 24.03 .2015 & 03.04 .2015 \\
\hline & 30.06 .2017 & 10.03 .2017 & 19.03.2018 & 23.03 .2017 & 04.04 .2017 \\
\hline
\end{tabular}


Table 2. The average values of pomological analysis of apricot types (2015-2017)

\begin{tabular}{|c|c|c|c|c|c|c|c|}
\hline Genotypes & Years & Fruit weight (g) & Brix Value (\%) & Total Acidity (\%) & $\mathrm{pH}$ & $\begin{array}{c}\text { Flesh Firmness } \\
\left(\mathrm{kg} / \mathrm{cm}^{2}\right)\end{array}$ & $\begin{array}{c}\text { Flesh/seed } \\
\text { Ratio (\%) }\end{array}$ \\
\hline \multirow{2}{*}{ '50-K-15’ } & 2015 & 61.93 & 18.00 & 0.46 & 4.80 & 0.8 & 21.20 \\
\hline & 2017 & 58.62 & 19.00 & 0.42 & 4.89 & 0.9 & 19.23 \\
\hline \multirow{2}{*}{ ‘50-K-17’ } & 2015 & 84.02 & 16.00 & 0.42 & 4.87 & 0.2 & 15.83 \\
\hline & 2017 & 82.54 & 17.00 & 0.64 & 4.56 & 0.5 & 14.52 \\
\hline \multirow{2}{*}{ '50-K-20’ } & 2015 & 67.61 & 18.00 & 0.64 & 4.45 & 0.5 & 18.66 \\
\hline & 2017 & 52.05 & 17.00 & 0.67 & 4.38 & 0.8 & 14.19 \\
\hline \multirow{2}{*}{ ‘50-K-57’ } & 2015 & 41.67 & 29.00 & 0.36 & 4.9 & 0.2 & 17.15 \\
\hline & 2017 & 39.24 & 28.00 & 0.42 & 4.6 & 0.8 & 14.51 \\
\hline \multirow{2}{*}{ ‘50-K-91’ } & 2015 & 36.38 & 31.00 & 0.28 & 4.7 & 0.5 & 17.76 \\
\hline & 2017 & 36.48 & 29.00 & 0.34 & 4.6 & 0.9 & 16.41 \\
\hline \multirow{2}{*}{ '50-K-92’ } & 2015 & 42.04 & 24.00 & 0.62 & 4.48 & 0.3 & 16.55 \\
\hline & 2017 & 39.48 & 21.00 & 0.74 & 4.65 & 0.9 & 17.17 \\
\hline \multirow{2}{*}{ ‘50-K-93’ } & 2015 & 34.23 & 28.00 & 0.41 & 4.6 & 0.3 & 14.63 \\
\hline & 2017 & 30.52 & 23.00 & 0.45 & 4.7 & 0.8 & 13.93 \\
\hline \multirow{2}{*}{ ‘50-K-95’ } & 2015 & 30.31 & 27.00 & 0.43 & 4.27 & 0.8 & 14.56 \\
\hline & 2017 & 32.50 & 25.00 & 0.52 & 4.32 & 0.9 & 14.62 \\
\hline \multirow{2}{*}{$50-K-96$} & 2015 & 33.45 & 26.00 & 0.34 & 5.17 & 0.3 & 11.44 \\
\hline & 2017 & 21.02 & 25.00 & 0.42 & 4.82 & 0.7 & 8.28 \\
\hline \multirow{2}{*}{ ‘50-K-97’ } & 2015 & 41.83 & 27.00 & 0.29 & 5.26 & 1.2 & 16.9 \\
\hline & 2017 & 35.60 & 26.00 & 0.32 & 5.12 & 1.4 & 16.13 \\
\hline \multirow{2}{*}{ '50-K-98’ } & 2015 & 42.90 & 22.00 & 0.38 & 4.96 & 0.5 & 13.86 \\
\hline & 2017 & 36.15 & 23.00 & 0.36 & 4.92 & 0.8 & 14.03 \\
\hline \multirow{2}{*}{ '51-K-06' } & 2015 & 33.57 & 28.00 & 0.46 & 5.12 & 0.3 & 11.21 \\
\hline & 2017 & 32.45 & 27.00 & 0.49 & 4.95 & 0.7 & 11.09 \\
\hline \multirow{2}{*}{ '50-K-130’ } & 2015 & 65.26 & 19.00 & 0.52 & 4.32 & 0.2 & 13.68 \\
\hline & 2017 & 62.30 & 18.50 & 0.65 & 4.40 & 0.6 & 13.52 \\
\hline 'Hacı & 2015 & 37.15 & 26.00 & 0.63 & 4.92 & 1.1 & 14.33 \\
\hline Haliloğlu' & 2017 & 33.75 & 26.00 & 0.56 & 4.63 & 1.2 & 13.49 \\
\hline \multirow{2}{*}{ 'Kabaaşı' } & 2015 & 26.01 & 20.00 & 0.39 & 4.68 & 1.1 & 10.94 \\
\hline & 2017 & 28.95 & 24.00 & 0.42 & 4.57 & 0.9 & 11.24 \\
\hline
\end{tabular}

\begin{tabular}{|c|c|c|c|c|c|c|c|c|}
\hline \multicolumn{9}{|c|}{ Blooming Date } \\
\hline & & \multicolumn{4}{|c|}{ March } & \multicolumn{3}{|c|}{ April } \\
\hline & & 15 & 20 & 25 & 31 & 5 & 10 & 15 \\
\hline \multirow{3}{*}{$50-\mathrm{K}-15$} & 2015 & & & & & & & \\
\hline & 2017 & & & & & & & \\
\hline & 2015 & & & & & & & \\
\hline \multirow[t]{2}{*}{ 50-K-17 } & 2017 & & & & & & & \\
\hline & 2015 & & & & & & & \\
\hline \multirow[t]{2}{*}{$50-\mathrm{K}-20$} & 2017 & & & & & & & \\
\hline & 2015 & & & & & & & \\
\hline \multirow[t]{2}{*}{$50-K-57$} & 2017 & & & & & & & \\
\hline & 2015 & & & & & & & \\
\hline \multirow[t]{2}{*}{$50-\mathrm{K}-91$} & 2017 & & & & & & & \\
\hline & 2015 & & & & & & & \\
\hline \multirow[t]{2}{*}{$50-K-92$} & 2017 & & & & & & & \\
\hline & 2015 & & & & & & & \\
\hline \multirow[t]{2}{*}{$50-\mathrm{K}-93$} & 2017 & & & & & & & \\
\hline & 2015 & & & & & & & \\
\hline \multirow[t]{2}{*}{$50-K-95$} & 2017 & & & & & & & \\
\hline & 2015 & & & & & & & \\
\hline \multirow[t]{2}{*}{$50-K-96$} & 2017 & & & & & & & \\
\hline & 2015 & & & & & & & \\
\hline \multirow{2}{*}{$50-K-97$} & 2017 & & & & & & & \\
\hline & 2015 & & & & & & & \\
\hline \multirow[t]{2}{*}{$50-K-98$} & 2017 & & & & & & & \\
\hline & 2015 & & & & & & & \\
\hline $50-\mathrm{K}-130$ & 2017 & & & & & & & \\
\hline \multirow{3}{*}{$51-\mathrm{K}-06$} & 2015 & & & & & & & \\
\hline & 2017 & & & & & & & \\
\hline & 2015 & & & & & & & \\
\hline \multirow[t]{2}{*}{ Hacıhaliloğlu } & 2017 & & & & & & & \\
\hline & 2015 & & & & & & & \\
\hline Kabaaş1 & 2017 & & & & & & & \\
\hline
\end{tabular}

Fig. 1. Blooming dates of the selected genotypes 

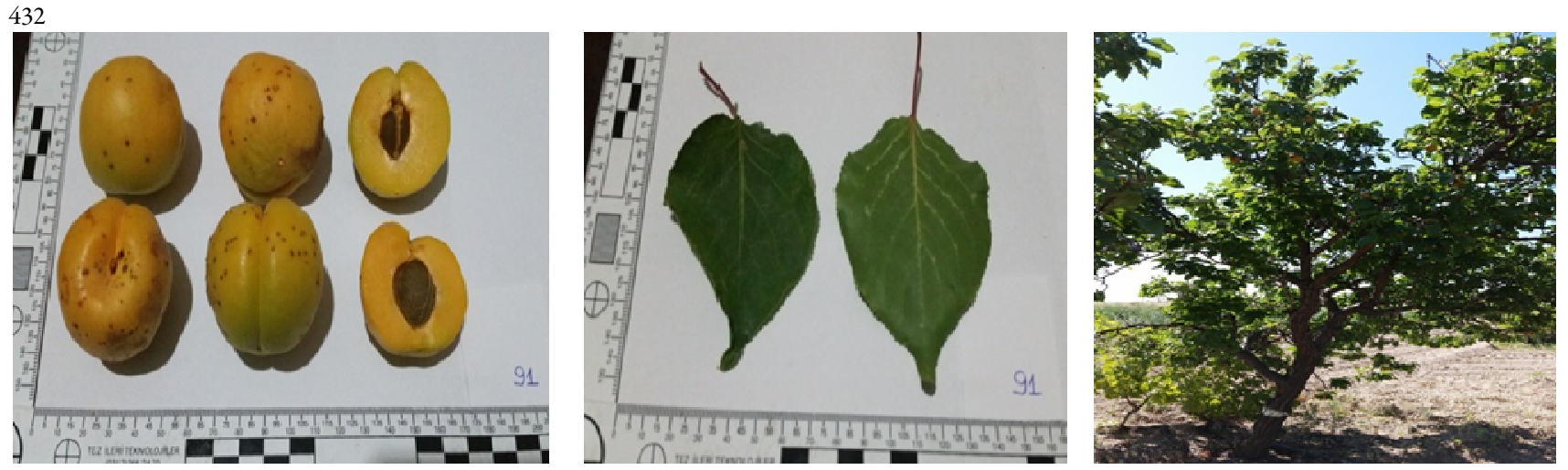

Fig. 2. Fruits, leaves and tree of genotype '50-K-91'

\section{Conclusions}

In this study, it was aimed to select genotypes having good dry fruit characteristics for dry apricot cultivation. Besides this, fruit quality performances such as fruit size, higher Brix value, taste, aroma and fruit flesh firmness were also examined in the study.

The low temperatures, especially experienced in 2015, provided an opportunity to select tolerant genotypes to late spring frosts. Tolerance to low temperatures was also important for both dry and table apricot production. Genotypes from which fruits can be collected were considered as promising in terms of frost tolerance. It is beneficial to continue observations and evaluations with the genotypes in the coming years for the second stage of the selection. By this way, the identified genotypes could be used as parents in breeding studies to develop new varieties tolerant to cold weather conditions.

In the experimental areas, production is mostly carried out in dry climatic conditions in which irrigation and fertilization is not performed on apricot trees. Therefore, the fruits remain relatively small. The fruit size of the irrigated and fertilized trees was found to be larger such as; '50-K-15', '50-K-17', '50-K-20', '50-K-129' and '50-K-130' genotypes. It is evaluated that irrigation and fertilization especially in the second rapid development period, in which the cell growth and the development of intercellular spaces occur in fruits, would increase the size of the fruit.

The Brix value of $31 \%$ obtained in this selection study is quite high compared to the Brix values obtained in the previous studies. It is possible to express that there is a population in the selected region with similar level Brix value which is the most important factor for dry apricots. Also, the fruits with high Brix value have more drying efficiency than the others. As it is known that, apricot cultivation is concentrated in Malatya province in Turkey. 'Hacıhalioğlu' variety, which has superior drying qualities, is used in cultivation. These selected dry apricot genotypes are capable of competing with 'Hacihaliloglu' and could be adaptable to the other regions. Some of the genotypes examined in the study are considered to have advantageous for both high Brix values and relatively tolerance to the late spring frosts seen during the flowering period in 2015. In the following years, it is possible to study the adaptation of the genotypes in both their own growing areas and in other apricot growing regions in terms of late spring frost tolerance.
It was estimated that low fruit weight of some of the selected apricot genotypes would increase and be compatible with the productivity if the cultural operations such as irrigation, pruning, fertilization, disease and pest control are carried out in conformity with the purpose.

In conclusion, considering the fruit characteristics of dry and table type high quality apricot genotypes, which were grown from seeds and extensively produced in Nevsehir and Nigde regions for a long time, were identified in this study. This study will help to introduce new dry or table apricots could be an alternative to 'Hacihaliloglu' apricot variety.

\section{Acknowledgements}

We would like to thank the Scientific Research Projects Unit of Çukurova University for the support of this study. (Project No: FDK-2015-3718).

\section{Conflict of Interest}

The authors declare that there are no conflicts of interest related to this article.

\section{References}

Akca Y, Askn A (1995). Clonal selection in apricot cultivar Hachaliloglu. Acta Horticulturae 384:169-171.

Akca Y, Sen SM (1999). Studies on selection of apricots with good fruit quality and resistance to late spring frost in Gevas Plain. Acta Horticulturae 488:135-137.

Asma BM (2007). Malatya: the world's capital of apricot culture. Chronica Horticulturae 47:20-24.

Asma BM (2012). New apricot selections for dried and table consumption in Eastern Anatolia-Turkey. 15 $5^{\mathrm{t}}$ ISHS international symposium on apricot breeding and culture. Acta Horticulturae 966:291-294.

Bircan M, Pinar H, Yllmaz C, Yildız A, Kargi SP, Kaska N (2008). The apricot breeding programme among some Turkish and foreign cultivars. $14^{\mathrm{h}}$ international symposium on apricot breeding and culture. Acta Horticultuare 862:103-107.

Bolat I, Guleryuz M (1995). Selection of late maturation wild apricot (Prunus armeniaca L.) forms on Erzincan Plain. 10 $10^{\text {th }}$ international symposium on apricot culture. September 20-24, 1993, Izmir. Acta Horticulturae 384:183-187. 
Durgac C (2001). Sakıt kayıslarnın seleksiyonu, meyve büyüme durumlan ve Sakıt vadisinin soğuklanma sürelerinin belirlenmesi. $\mathrm{PhD}$ thesis, Çukurova Üniversitesi Fen BilimleriEnstitüsü.

Guerriero R, Watkins R(1984). Revised descriptor list for apricot (Prunus armeniaca L.). International board for plant genetic resources. Rome, Italy.

Özbek S (1978). Özel Meyvecilik. Çukurova Üniversitesi Ziraat Fakültesi YayınlarıNo:128,pp386.

Ozyoruk C, Guleryuz M (1992). Iğdır ovasında yetişen kayısı çeşitleri üzerine pomolojik, biyolojik ve fenolojik araştırmalar. Master thesis, Atatürk Üniverstesi Fen Bilimleri Enstitüsü.
Pinar H, Bircan M, Yllmaz C, Karg Paydas S, Kaska N, Yıldız A, Son L (2010). The performance of some apricot cultivars in the Mersin ecological conditions. Acta Horticulturae 862:109-112.

Sen SM, Tekintas MEM, Askın A, Cangi R, Boston SZ, Balta F, ... Akca Y (1995). Researches on breeding by selection of wild apricot (Prunus armeniaca L.) forms in Adilcevaz Plain. Acta Horticulturae 384:201204. 